\title{
Energy recovery of grass biomass
}

\author{
S. Oldenburg, L. Westphal \& I. Körner \\ Hamburg University of Technology, Germany
}

\begin{abstract}
Not only due to the actual climate change, but also in consideration of exhaustible resources, alternative energy supplies for the steadily growing energy demand need to be found. The main emphasis should be placed on the substitution of fossil fuels with agricultural by-products and other organic materials. Especially, the utilisation of fresh grass or grass silage of extensively cultivated farm land has great potential as an energy feedstock, as in agriculture this bio-resource is currently considered a waste material and is neither economically nor ecologically utilised in an efficient way. Additionally, the lawn-clippings, which are accumulating as communal and private waste could be used for energy production since many local authorities have problems with utilising this gramineous waste. Thus, for anaerobic digestion big amounts of grass biomass and lawn substrates are available from farmers and landscape conservation. In order to evaluate the suitability of this material for biogas plants in the first place, a detailed inventory needs to be conducted. This was exemplarily done for the Hamburg District Bergedorf $\left(155 \mathrm{~km}^{2}\right)$. The result shows that approximately $10,000 \mathrm{Mg} / \mathrm{a}$ of grass and lawn clippings could theoretically be made available. By laboratory investigations, in batch tests, the theoretical biogas potentials of selected grass and lawn substrates were determined. A statement about the suitability of the substrates for anaerobic digestion is made in this paper. The biogas potentials are between 325 and 720 standardized 1 per $\mathrm{kg}$ organic dry matter ( $/ / \mathrm{kg}$ ODM), depending on the sampling location, mowing time, grass species etc. For example, the biogas potentials for clippings from the dikes were in a range comparable with corn silage between 420 and 700 1/kg ODM. Additionally, the problem of seasonal accumulation of grass biomass including the influence of storage on the initial material is considered in this paper.
\end{abstract}

Keywords: grass, lawn, digestion, biogas potential. 


\section{Introduction}

Climate protection is an important part of the challenges of environmental politics nowadays. To prevent the progress of global warming, climate protection agreements have been established according to which a great amount of the energy demand has to be provided by renewable energies in the near future. The substitution of fossil energy sources by renewable bio-resources will inevitably lead to less emission of carbon dioxide. Moreover, renewable resources are an important and versatile energy source since they can be utilized for heat, fuel and electricity. A crucial point is the possibility of storage and flexible utilisation. Because of this, the cultivation of energy crops, especially corn, increased in Germany in the last years enormously. But at this point, the competition for cultivable areas between energy crops and food products has to be considered. Eventually other conflicts of interests will rise up between bio-energy providers, nature conservation and tourism, given that much grassland was converted to farmland for growing energy crops. A better opportunity could be the use of plants and green waste that arises from countryside preservations and which cannot be used for the food production. There are an estimated $900,000 \mathrm{Mg}$ of green waste available in Germany per year, which originate from nature and biotope areas [1]. Additional grass fractions are generated in agricultural excess areas or lean grass fields. Usually these resources have to be collected from the land on a regular basis to prevent accumulations of nutrients in the soil and preserve the biological ecosystem. Furthermore, due to the decrease of cattle farming in some regions, the green waste from the farmland formerly used for cattle feed production needs to be disposed of. These areas are then only serviced without utilisation of the grass. The maintenance of public parks, sport fields and gardens are other sources of grass. In Germany an estimated 300,000 Mg/a of such green waste is generated [1]. In conclusion, grass fractions are available in huge amounts from private and commercial sources as well as from landscape maintenance. The goal of this work is an evaluation of grass fractions as substrate for biogas generation. The yield of grass biomass per area has exemplarily been investigated for one district of Hamburg. This energetically usable biomass derives from extensive grasslands, fields of grass and farmland; it is either disposed waste or utilised up to now. The amount of this biomass has been investigated and experiments were performed to determine its energetic potential. The results can be transferred to different areas and regions to draw a final conclusion: whether it makes sense to energetically utilize the unused or disposed grass and lawn waste as a substrate in biogas plants, or not.

\section{Definitions}

Grassland and pasture is defined as agricultural land that has been set up by humans. The grass has to be cut on a regular basis to prevent a scrub encroachment [2]. Grass, herbs and leguminous plants grow on grassland. Depending on the farming of the land grass usually represents the majority of the present vegetation in Germany. This is due to the selection caused by mowing 
the land repeatedly, since grass is able to regenerate and re-grow very fast. Thus the ratio of grass increases with intense farming of the land. $29 \%$ of the agricultural areas of Germany are grasslands [3]. A field of lawn is defined to be an area which includes many different kinds of grass, but no herbs or leguminous plants at all. To maintain a good optical view, the lawn is usually kept at a length of two to ten centimetres. Therefore it has to be mowed up to 40 times a year [4]. Fields of lawn are maintained for the purpose of sports, recreation and a positive representation. About 5\% of the entire area of Germany is kept as lawn of some sort [5].

\section{Inventories}

The district of Bergedorf covers an area of $155 \mathrm{~km}^{2}$, which represents $20 \%$ of the entire area of Hamburg, including 13 different quarters. The district itself could be split into two different parts: an urban part and a rural part, which makes up about $75 \%$ of the area. Most of the quarters are agrarian and have a small population density. Overall there are about 120,000 residents living in the district of Bergedorf, averaging at 760 people per $\mathrm{km}^{2}$. There are only three quarters with a population density of more than 1,000 people per $\mathrm{km}^{2}$. The other ten quarters are sparsely populated with no more than 400 residents per $\mathrm{km}^{2}$. The grassland is about two times as large as the cultivated land with an area of $53 \mathrm{~km}^{2}$. More than half of the area is being used agriculturally. The area used for buildings, infrastructure, business and the open space add up to only about $26 \%$.

Almost half of Hamburg's agricultural land is located in the district of Bergedorf whereas the cultivated land in the entire city is only about $10 \%$. Altogether all different structures of a city are present in the district of Bergedorf: ranging from urban regions to less densely populated parts and from agricultural land to nature preserve areas. The calculation of the dry mass yield of grass fractions was performed using the land use of the city, values from literature and average values. Additionally all results presented in this paper refer to the generation within one year. Furthermore the dependencies on location, climate and cultivation have been considered in the calculations.

\subsection{Fields of grass}

The actual yield potentials of the different grasslands are hard to approximate. There are literature values, but the yield can differ depending on the location and nutrient content of the ground. The grassland was categorized into two different main groups, whereat the areas have mostly been assigned to their cultivation. The first group is the intensively managed grassland, which are intensively used fertile meadows in agriculture whose grass is used to feed the cattle. The second group is the extensively managed grassland. This is used in accordance with the administration. The areas are used for conservation or recreation; some of them are defined as compensation areas. The entire potential of the whole grassland is about $8,100 \mathrm{Mg}$ of dry matter in the district of Bergedorf per year. This is 
$67.5 \mathrm{~kg}$ per resident and year. In the following sections, the calculations are shown and explained.

\subsubsection{Intensively managed grassland}

To determine the potential of intensively farmed meadows, letter-surveys have been conducted. 81 were sent to farmers in Bergedorf via the department of agriculture. The grass from intensively managed grassland is only available for further energetic utilization if the outgrowth could not be utilized in another way. The reasons why the mowing is not used completely, are, for example, a lack of cattle, a bad quality of the year's harvest or plant populations that cannot be consumed by the cattle. Mowing and gathering this kind of grass could only be considered if an allowance was paid for this work. The average yield from mowing three to six times per year is about 0.8 and $1.2 \mathrm{~kg}$ of dry matter per square meter and year [6]. For a yield of $0.85 \mathrm{Mg}$ of dry matter per square meter and year there is a potential of about $1,780 \mathrm{Mg}$ of dry matter per year from intensively managed grassland.

\subsubsection{Extensive managed grassland}

There are five different kinds of grass areas in the district of Bergedorf, which are extensively managed: dikes, public fields of grass, compensation areas, contracted nature preservation and nature preserve areas. The dikes, the public fields of grass and compensation areas are fertilized with liquid manure or dung in part. Then the yield per year and square meter is less than $0.6 \mathrm{~kg}$ for cutting it twice a year [6]. Land that is not being used to produce animal food and must not be fertilized, as contracted nature preservation areas have a yield of biomass production less than $0.35 \mathrm{~kg}$ of dry matter per year and square meter [6]. Nature reserve areas will be considered to have a yield of $0.15 \mathrm{~kg}$ of dry mass per year and square meter [7].

The potential of dikes was computed using the average of the year 2010 and is about $600 \mathrm{Mg}$ of dry matter per year. Most of the outgrowths are disposed by composting, a process that causes costs. Gathering of the material is expensive and the incline of these fields impedes this process as well. The maintenance of the areas that are under contracted nature preservation is tied to distinct contracts with the farmers of Bergedorf and the agricultural use as pasture or mowed meadow is defined. These areas can be mowed starting at the first of July; the responsibility of this action was transferred to the farmers. The farmers are obliged to remove the cut grass for preventing an accumulation of nutrients on the ground. For the purpose of disposing this material it is commonly used as litter for the animal sheds. This is not the best solution and it does not represent the optimum utilization of the material. It takes years up to decades until the land is depleted and there are different meadows with larger or smaller yields. Land having very small yields due to the weather can usually only be cut once a year. Cattle are sent on some of this land after cutting the grass, then the amount from the second cut decreases, too. By the fact that these areas are farmed by ecological means, indicating that the first time of cutting the grass is done very late and a second cutting does not always take place, a potential of about 
$1,300 \mathrm{Mg}$ of dry mass of grass per year from areas that are under contracted nature preservation is theoretically available.

Notice has to be taken of the partial swamp land and the areas that are hard to access, properties that complicate collecting the material. Additionally when cutting the grass very late they contain an increased amount of lignin, which can cause problems during the biogas production. The maintenance of the present compensation areas in the district of Bergedorf and areas that are under a development plan is performed using similar conditions in the according contracts compared to the contracted nature preservation, but the use of the material from cutting is similar to the contract nature preservation. The mowing is only used occasionally for meadows with no cattle on it. These areas are partially fertilized using cattle dung. So they are considered as extensive grassland having yields of about $0.6 \mathrm{~kg}$ of dry matter per square meter and year by cutting twice a year. For grazed fields there is a computed value of $0.35 \mathrm{~kg}$ dry matter per square meter when cutting the grass. The second clipping is usually dried and used as litter in the cattle stables in September. This represents a bad compromise, since the quality of the material is not sufficient to use it as food and therefore it would have to be disposed. The theoretical potential was determined to be about $5,400 \mathrm{Mg}$ of dry matter per year from compensation areas.

For the nature preserve areas, proper calculations of the incoming amount of grass are very difficult, since maintenance is only done on rare occasions. The actions of maintenance are integrated into a maintenance schedule individually adapted to each nature preserve area. It is a matter of fact that a large amount of the material cannot be utilized, because a part of it has to remain in the nature preserve areas to preserve the natural circle. In addition, the areas are quite often difficult to access and agricultural vehicles are not allowed to drive there. By an energetic utilization and an according allowance for the outgrowth the maintenance of the nature reserve areas can be improved and a larger potential is possible. The yield is at about $0.15 \mathrm{Mg}$ of dry matter per square meter and year, because of a late cutting and due to a lack of available nutrients in the ground. Hence the potential of the biomass is estimated to be $280 \mathrm{Mg}$ of dry mass per year from nature preserve area.

There are many small companies, who are assigned to maintain public fields of grass. Those areas are only mowed about once or twice a year, so they belong to the group of less intensively managed grasslands and not to the group of lawn. Because of not fertilizing these areas the yield potential was estimated to be $0.35 \mathrm{~kg}$ of dry matter per square meter and year. So far the cut grass remains on the land and is not gathered, except for a small path. Currently, it is desirable to get less mowing. Nonetheless the disposed material is being composted which causes costs. From these results a biomass potential of 1,120 Mg dry matter per year from public fields of grass were detected. By mulching after clipping some nutrients are transported back into the ground and the yield could be increased. 


\subsection{Fields of lawn}

In this work fields of grass and lawns will be discussed separately, since their maintenance and composition of different kinds of grass are different. The fields of lawn of public grasslands, parks, sport fields, private gardens, single and apartment buildings have been considered for the calculations. The potential for public grassland with a total of 10 square $\mathrm{km}$ has been calculated on indications of the district office Bergedorf, surface structures and re-growth rates. In addition, the amounts which are partly collected are included in the calculations. A total of $490,000 \mathrm{~m}^{2}$ of lawn is cut by companies. It is not known how large the surface is which is cut from the District Office (Bezirksamt). It has made the assumption that at least another $20 \%$ of the total of 7 square kilometers of public green areas must be mowed. It was assumed that all areas are covered with grass, which has similar properties as the strain "Berlin Zoo". Since the area size is not precisely known, a much larger potential might be possible. With this calculation the potential of public grassland is estimated to $643 \mathrm{Mg}$ of dry mass per year.

A questionnaire was sent to all churches in Bergedorf. The response rate was very low. Therefore, only a reflection of the state church has been done. The result was about $10 \mathrm{Mg}$ of dry matter per year. Knowing that only one cemetery has been considered for calculating the potential, there will be much more grass waste that could not be included so far.

The sport fields in the district of Bergedorf could provide about $32 \mathrm{Mg}$ of dry matter per year, if this material would be gathered and not remain on the field. The potential yield of private yards and gardens of single, double and multiple apartments depends heavily on the settlement structure, the size of the gardens and their design.

In the urbanized parts of Bergedorf the grass potential for the one-and twofamily houses was calculated with an average of $34 \mathrm{~kg}$ of organic waste per inhabitant per year. This value comes from the estimation of the Ministry of Urban Development and Environment, which is in Hamburg for about $60,000 \mathrm{Mg}$ of organic waste per year recycled about private composting [8]. For the remaining eleven city quarters, this value could not be applied because of their rural structures. Therefore the garden sizes and structures were determined by sending letters and surveys to the residents and by performing green waste sorting. In addition, the re-growth rates and expected care measures were calculated. It is to be remarked that the calculated potential reflects actual and realistic values, if proper collection procedures are introduced and the residents are well informed concerning the separation of different kinds of waste. The computed potential from private households is about $4,400 \mathrm{Mg}$ of dry matter per year. The whole potential of lawn is about $5,070 \mathrm{Mg}$ of dry matter per year.

\subsection{Summary}

There is an overall theoretical potential of $15.550 \mathrm{Mg}$ of dry matter per year of intensively and extensive managed grassland and lawn. 
Table 1: List of the potential yields of grass in the district of Bergedorf.

\begin{tabular}{|c|c|}
\hline Area & Dry matter [Mg/a] \\
\hline Intensive grassland & 1,780 \\
\hline Extensive grassland & 8,700 \\
\hline Fields of lawn & 5,070 \\
\hline Total & $\mathbf{1 5 , 5 5 0}$ \\
\hline
\end{tabular}

\section{Anaerobic digestion of grass fraction}

Biogas is a mixture which primarily consists of two components: methane $\left(\mathrm{CH}_{4}\right)$ and carbon dioxide $\left(\mathrm{CO}_{2}\right)$. It is generated by the degradation of organic matter in the absence of oxygen. The technically usable process of this anaerobic degradation is called digestion, which is enabled by complex interactions of different microorganisms. The degradation proceeds step by step and can be broken down into four different states that are referring to the involved microorganisms: Hydrolysis, Acidogenesis, Acetogenesis and Methanogenesis. Being the prime combustive compound, methane basically determines the properties and the energetic usage of the biogas. It is an energy source with a high yield and has the calorific value $50 \mathrm{~kJ} / \mathrm{kg}$ in under standardized condition and represents about two thirds of the overall colorific value of natural gas [9].

A detailed literature research has shown that the biogas potential of grass varies between 500 to $700 \mathrm{l} / \mathrm{kg} \mathrm{ODM}$ and is quite different concerning the structures of the land or the agricultural methods. In consequence, the gas potentials of many different grass samples were determined by theoretical models, elementary analyses, as well as by laboratory experiments of exemplary samples of the district of Bergedorf. The calorific value determined by thermal oxidation serves for comparison in section 5. Choosing the particular grass substrates was the priority to the broad range of different areas and characteristics. All of the samples have directly been collected in the district of Bergedorf and cover all areas considered in the inventory. Altogether 16 different substrates have been investigated; nine substrates of extensive managed grassland, four different lawns and one of intensive managed grassland.

\subsection{Determining the theoretical biogas potential}

Using elemental analysis all ratios of carbon, nitrogen, sulfur and phosphor of the different substrates can be determined. The results are listed in table 2 . The content of carbon of the grass samples was between $45 \%$ and $47 \%$ of the dry matter. The content of nitrogen varied in a range from $0.72 \%$ for outgrowths of nature preserves areas up to $37 \%$ in case of public fields of grass. The highest value of nitrogen can be lead back to cut grass that has been left on the ground aggregating nutrients.

The ratio of carbon to nitrogen $(\mathrm{C}: \mathrm{N}$ ratio) is crucial to the gas yield. If the ratio is too small, the organic substance of the substrate cannot be degraded completely. This is the cases for very low crude fibre contents, as well. The 
optimum ratio is reported to be between 21:1 and 40:1 [10]. For ratios lower than $16: 1$ the gas yield is expected to decrease, since there is a lot of redundant nitrogen. The maximum ratio should be 45:1. Many samples were in the optimum range, only the samples of dike clipping $\mathrm{c}$ and $\mathrm{d}$, as well as the areas in the nature preserve areas had too low nitrogen contents (table 2). The phosphoric content of the grass samples from this district, except for the ordinary maintained grass of gardens and yards, are lower than the suggested literature values of $0.14 \%$ to $0.19 \%$ phosphor in the dry matter [11]. This increased phosphorous content can be lead back to the fertilization in spring. The chlorine content of the substrates is in a range of $0.23 \%$ up to $1.16 \%$ in the dry matter. The literature values are $0.31 \%$ for festuca arundinacea and $1.39 \%$ for grass of pasture and are not exceeded by the substrates of district Bergedorf. In contrast, the sulphuric content is higher: up to $0.3 \%$ sulfur in the dry matter. The literature values are between $0.14 \%$ and $0.19 \%$. Sulphur is an essential component for microorganisms that are present in a digester. Not solved resp. dissociated hydrogen sulphide is toxically and can hinder the biogas production if it is present in increased concentrations.

Table 2: Elemental composition of the samples.

\begin{tabular}{|c|c|c|c|c|c|}
\hline Substrate & $\mathbf{C}$ & $\mathbf{N}$ & $\mathbf{P h}$ & $\mathbf{S}$ & $\mathbf{C : N}$ \\
\hline Unit & \% TS & \% TS & \% TS & \% TS & \\
\hline Public meadow & 47.1 & 2.4 & 0.08 & 0.30 & $23.2: 1$ \\
\hline Dike clipping (a) & 46.6 & 1.9 & 0.04 & 0.18 & $29.4: 1$ \\
\hline Dike clipping (c) & 46.0 & 0.7 & 0.10 & 0.15 & $69.1: 1$ \\
\hline Dike clipping (d) & 45.6 & 0.8 & 0.13 & 0.19 & $69.2: 1$ \\
\hline $\begin{array}{c}\text { Nature preserve area } \\
\text { Grass of gardens and } \\
\text { yards (ordinary) }\end{array}$ & 46.8 & 0.8 & 0.13 & 0.16 & $74.5: 1$ \\
\hline $\begin{array}{c}\text { Grass of gardens and } \\
\text { yards (properly) }\end{array}$ & 34.5 & 1.7 & 0.10 & 0.27 & $25.0: 1$ \\
\hline Public fields of grass & 44.2 & 1.9 & 0.13 & 0.24 & $27.7: 1$ \\
\hline
\end{tabular}

One possibility to theoretically determine the maximum biogas potential is to perform calculations including the elemental composition and to use the Buswell-equation that has been modified by Boyle. Regarding that a complete digestion of the organic substance only is possible up to a maximum of $83 \%$ the theoretical gas yield results in an average value of 820 1/kg ODM (table 3).

\subsection{Practical biogas potential determination}

The biogas potential has been determined by batch tests under laboratory conditions according to VDI-standard no. 4630 in triplicate. Digestion test in the 
batch procedure allow drawing conclusions on the actual biogas yield and the anaerobic degradability of certain matters or solutions. Furthermore a qualitative estimation of the speed of the anaerobic digestion of certain substances and possible inhibitors in the examined concentrations of these substances can be conducted. The results are presented in fig. 1, including a reference curve with corn.

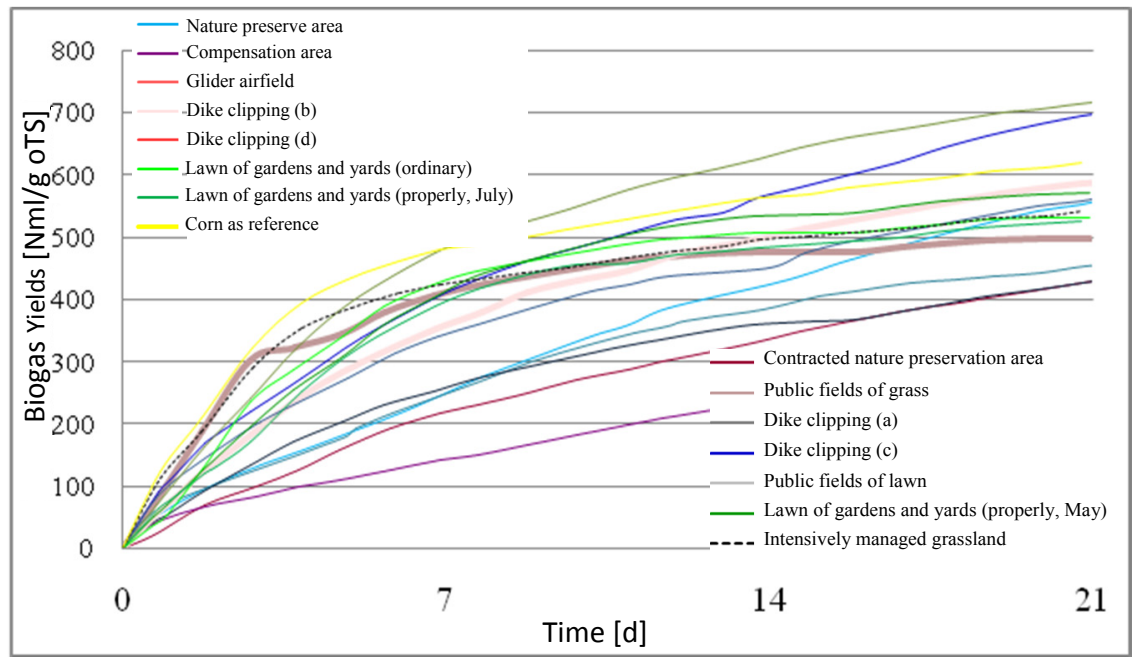

Figure 1: Biogas yields of different grass samples.

The gas yield of the silage of intensively managed grassland is $545 \mathrm{ml}_{\mathrm{N}} / \mathrm{g}$ ODM and therefore is a little bit lower than the yields of the outgrowths of nature preserve areas and of levee areas of the first time of cutting it from the end of May to the beginning of July. Since this sample was one of the late clippings of September, the latter were expected to produce less gas. These values are confirmed by literature [12]. The gas yields of extensively cultivated meadows ranged from $325 \mathrm{ml}_{\mathrm{N}} / \mathrm{g}$ ODM for silages of the compensation areas up to $705 \mathrm{ml}_{\mathrm{N}} / \mathrm{g}$ ODM for dike clippings (c). For these experiments the gas yields of silages are clearly below the yield of the not conserved outgrowths. The gas production of the silage of the compensation areas and the contracted nature preserve areas $\left(325 \mathrm{ml}_{\mathrm{N}} / \mathrm{g}\right.$ ODM and $445 \mathrm{ml}_{\mathrm{N}} / \mathrm{g}$ ODM) is less than the gas production of the second dry clipping of the glider airfield with $460 \mathrm{ml}_{\mathrm{N}} / \mathrm{g}$ ODM. Except for the outgrowths of public fields of grass the substrates of extensive meadows do not show any signs of being hemmed during the gas production. The curve of the gas production shows an obvious sharp bend at the beginning. This might be due to both the high content of nitrogen $(2.4 \%)$ and an eventual hemming because of ammonia. The gas yield of lawn substrates is in the range of the extensive meadows except for the clippings from the communal maintenance of the public fields of grass. This clipping has an increase in the gas production rate of $720 \mathrm{ml}_{\mathrm{N}} / \mathrm{g}$ ODM. Ordinary maintained grass of gardens and yards has a 
production rate of $530 \mathrm{ml}_{\mathrm{N}} / \mathrm{g} \mathrm{ODM}$, as the properly maintained grass with $525 \mathrm{ml}_{\mathrm{N}} / \mathrm{g}$ ODM for the clipping of May and $570 \mathrm{ml}_{\mathrm{N}} / \mathrm{g}$ ODM for the material of June. The C:N-ratio of the grass substrates are in the optimum range compared to the extensive meadows. Despite the good expectations from this concerning the digestibility of the grass, compared to extensive meadows, the experiments show similar levels of degradability of the organic substance of $64.2 \%$ for proper maintained grass and of $71.6 \%$ for the public fields of grass.

Concerning literature no losses were predicted, but problems during the ensiling of late clippings were known, since the large structures cannot be densified. The gas yield of both silages, which had $325 \mathrm{ml}_{\mathrm{N}} / \mathrm{g}$ ODM and $445 \mathrm{ml}_{\mathrm{N}} / \mathrm{g}$ ODM, definitely is less than the yields of not conserved outgrowths. Therefore a possible loss due to ensilaging has to be considered. Additionally fresh material and material that has been dried on the dike for two days were compared. The wet material surpassed the dry material with $705 \mathrm{ml}_{\mathrm{N}} / \mathrm{g}$ ODM compared to $520 \mathrm{ml}_{\mathrm{N}} / \mathrm{g}$ ODM. Thus there should be a decrease of the biogas potential when drying the material. This was an expected result, since the elemental analysis showed a decrease of the carbon content of $45.99 \%$ to $45.63 \%$ during dehydration.

\section{Combustion}

The utilization of the outgrowths can be processed using one of two possible methods. Fresh grass or silage can be digested in a biogas plant or it can be combusted. Because of that a reference is analyzed to determine the calorific value of the gas potential of the samples. The calorific value $\mathrm{H}_{\mathrm{U}}$ is defined to be the maximum usable amount of heat during combustion (DIN EN 14918).

Utilizing the grass and lawn clippings is only possible to a certain extent, since some of the properties of the grass stalk are disadvantageous to the combustion process. Sophisticated firing methods and an extended off-gas treatment require much more effort. On the one hand this leads to the exhaustion of more chloral, nitrogen, potassium or sulphuric gases, on the other hand there are increased amounts of ashes, causing higher rates of pollutant emissions and increasing the costs of the firing system. The amount of ashes of the lawn substrates is about $20 \%$, which is more than the ashes of average grass clippings, which is about $9 \%$. Wood is producing a significantly smaller amount of ash, about $0.5 \%$ [11]. Additionally the utilization of recently harvested plants is more difficult, since the material is very moist and would have to be dried before firing it. Moisture contents of more than 20\% [13] cause the combustion to be inefficient and drying it would require several additional mechanical operations.

Table 3 shows the average moisture contents and amounts of ashes for the samples from the district of Bergedorf. The moisture content is more than the required $20 \%$. The caloric values are about $9 \%$ below the average caloric value of wood which is $18.5 \mathrm{MJ} / \mathrm{kg}$ TS [14]. 
Table 3: Biogas yields, caloric values, moisture contents and amounts of ashes.

\begin{tabular}{|c|c|c|c|c|c|}
\hline Substrate & $\begin{array}{l}\text { Theoretic } \\
\text { Biogas } \\
\text { production }\end{array}$ & $\begin{array}{c}\text { Biogas } \\
\text { production }\end{array}$ & $\begin{array}{c}\text { Caloric } \\
\text { value } \\
\mathbf{H}_{\mathrm{u}}\end{array}$ & $\begin{array}{l}\text { Moisture } \\
\text { content }\end{array}$ & $\begin{array}{l}\text { Amount } \\
\text { of ashes }\end{array}$ \\
\hline Unit & $1 / \mathrm{kg}$ ODM & 1/kg ODM & $\mathrm{kJ} / \mathrm{kg}$ & $\%$ ODM & $\% \mathrm{TS}$ \\
\hline $\begin{array}{l}\text { Intensively managed } \\
\text { grassland }\end{array}$ & & 545 & & & \\
\hline \multicolumn{6}{|l|}{ Extensive grassland } \\
\hline Public meadow & 852 & 500 & 16,537 & k.A. & 12.9 \\
\hline $\begin{array}{l}\text { Silage from } \\
\text { compensation area }\end{array}$ & 812 & 325 & & & \\
\hline Glider airfield & & 460 & & & \\
\hline Dike clipping (a) & 812 & 705 & 16,928 & 56.1 & 8.4 \\
\hline Dike clipping (c) & 789 & 620 & 16,409 & 70.2 & 8.6 \\
\hline Dike clipping (d) & & & 16,356 & 38.7 & 8.3 \\
\hline Nature preserve area & 773 & 445 & 16,157 & 64.2 & 7.8 \\
\hline \multicolumn{6}{|l|}{ Fields of grass } \\
\hline $\begin{array}{l}\text { Lawn of gardens and } \\
\text { yards (ordinary) }\end{array}$ & 878 & 530 & 16,684 & 82.4 & 13.2 \\
\hline $\begin{array}{l}\text { Lawn of gardens and } \\
\text { yards (properly) }\end{array}$ & 726 & 545 & 12,047 & 57.7 & 40.6 \\
\hline Public fields of lawn & 851 & 720 & 16,710 & 60.2 & 14.8 \\
\hline
\end{tabular}

\section{Summary}

Because of the increased energetic use of biomass the competition for agricultural land between energy crops and actual feed crops was intensified. In addition the decrease of cattle farming in Germany frees grassland which has to be maintained. An energetic utilization of so far unused or not efficiently used green waste would be an important step for the improvement and there exists a large untapped potential. Based on the results of this paper a comparison of the theoretical and practical biogas potential as well as the combustion can be made.

The reference was given by different literature values which varied in a range of $500 \mathrm{ml}_{\mathrm{N}} / \mathrm{g}$ ODM up to $700 \mathrm{ml}_{\mathrm{N}} / \mathrm{g}$ ODM. The practical biogas production was determined by laboratory digestion experiments. The theoretical biogas production was determined by an element analysis via the modified Buswellequation. The theoretical potential was between $800 \mathrm{ml}_{\mathrm{N}} / \mathrm{g}$ ODM and $878 \mathrm{ml}_{\mathrm{N}} / \mathrm{g}$ ODM and much higher than the results of the laboratory tests. The practical experiments displayed a good degradability and resulted in values between $325 \mathrm{ml}_{\mathrm{N}} / \mathrm{g}$ ODM and $720 \mathrm{ml}_{\mathrm{N}} / \mathrm{g}$ ODM depending on the material and its storage. Looking at figure 1 a rapid digestion seems to be clear, identifiable by the strong plateau phase. This indicates a good anaerobic degradation of the substrate. After 
21 days the gas production was still at about $2.5 \%$ of the so far produced gas. Testing for a longer period should result in higher gas yields. In addition, more optimization opportunities under the anaerobic digestion and the silage-process must be found. The energetic utilization by fermentation is the best option, because the carbon cycle can be closed with digestate. Late clippings of autumn and the grass of extensive land feature a low gas yield, so the combustion of these outgrowths could be an alternative method. For the economic energy a lot of factors, i.e. different temperatures during the fermentation, the storage, treatment and collection processes and co-substrates, have to be investigated.

\section{References}

[1] Rösch, C., Vergleich stofflicher und energetischer Wege zur Verwertung von Bio- und Grünabfällen. In: Wissenschaftliche Berichte FZKA 5857, S. 269, 2005.

[2] Pfadenhauer, J., Vegetationsökologie. A script, with 64 tables. 2. expanded edition, Eching near München: IHW-Publisher., 1997.

[3] Prochnow, A., Heiermann, M., Idler, C., Linke, B., Mähnert, P. \& Plöchl, M., Biogas vom Grünland:Potenziale und Erträge, Leibniz Institute of Agricultural Engineering PODMdam-Bornim, 2007.

[4] Degenbeck, M., Bavarian State Institute for Viticulture and Horticulture [Hrsg.]): Basiswissen Rasenbau. Anlage und Pflege von Rasenflächen, In: Deutscher Gartenbau, Heft 4; S. 10-12.

[5] Turf specialist agency (University Hohenheim [Hrsg.]): Kompetenz für Rasen. With the collaboration of Hartmut Schneider und Wolfgang Hendle., 2007. https://www.uni-hohenheim.de/rasenfachstelle/ [Accessed 29.09.2010]

[6] Buske, M. (MOVECO GmbH [Hrsg]), Grünland-Abgerenzung, Definition und Unterteilung, 2010. http://www.architektenleistungen.de/article /Grünland [Zugriff am 15.10.2010]

[7] Oechsner, H. (Universität Hohenheim [Hrsg.]), Verfahrenstechnik der Vergärung von Biomasse. State Institute of Farm Machinery and Construction, in collaboration with the Academy for Nature and Environmental Protection of Baden Wuerttemberg, Stuttgart, 2005.

[8] Freie und Hansestadt Hamburg, Ministry of Urban Development and Environment [Hrsg.]): Nationalpark und Naturschutzgebiete in Hamburg, 2010. http://www.hamburg.de/contentblob/202306/data/bsu-nsg-tabelle.pdf [Accessed 14.10.2010]

[9] Hofmann, J. (Regierung Niederbayern. Landshut [Hrsg.]), Grundlagen der Biogaserzeugung, Proceedings of the briefing on 13 July 2000 in the government of Lower Bavaria, 2001.

[10] Mähnert, P., Kinetik der Biogasproduktion aus nachwachsenden Rohstoffen und Gülle, Dissertation, Humboldt-Universität, LandwirtschaftlichGärtnerischen Fakultät, Berlin, 2007.

[11] Hartmann, H., Böhm, T. \& Maier, L. (Bavarian State Ministry for Regional Development and the Environment (Stmlu) [Hrsg.]), Naturbelassene 
biogene Festbrennstoffe. Umweltrelevante Eigenschaften und Einflussmöglichkeiten, München, 2000.

[12] Kaiser, F., Einfluss der stofflichen Zusammensetzung auf die Verdaulichkeit nachwachsender Rohstoffe beim anaeroben Abbau in Biogasreaktoren, Dissertation, Maintained by J. Bauer, Technische Universität München, Scientific Center Weihenstephan for Food, Environment and Land Use, 2007.

[13] Elsäßer, M. (Staatliche Lehr- und Versuchsanstalt für Viehhaltung und Grünlandwirtschaft. Aulendorf [Hsrg.], Möglichkeiten der Verwendung alternativer Verfahren zur Verwertung von Grünlandmähgut: Verbrennen, Vergären, Kompostieren. In: Reports on Agriculture, 2003.

[14] FNR e.V. [Hrsg.]: Leitfaden Bioenergie. Planung, Betrieb und Wirtschaftlichkeit von Bioenergieanlagen; 4., unchanged edition., 2007. 